\title{
Quality attributes of modified atmosphere packaged bell pepper (Capsicum annuum L.) during storage
}

\author{
Sharma KD, ' Cardona JA, ${ }^{2}$ Sibomana MS, ${ }^{3}$ Herrera NGS, ${ }^{4}$ Nampeera E, ${ }^{5}$ Fallik E \\ 'Department of Food Science \& Technology, DrYS Parmar University of Horticulture \& Forestry, Solan, India \\ ${ }^{2}$ Pan-American School of Agriculture, Tegucigalpa, Honduras \\ ${ }^{3}$ University of Kwazulu-Natal, Pietermaritzburg Campus, Bioresources Engineering, Kwazulu-Natal, South Africa \\ ${ }^{4}$ National University of Colombia, Bagota, Colombia \\ ${ }^{5}$ National Crops Resources Research Institute, Kampala, Uganda \\ ${ }^{6}$ Agricultural Research Organization, Bet Dagan, Israel
}

Correspondence: Krishan D. Sharma, Department of Food Science \& Technology, Dr YS Parmar University of Horticulture \& Forestry, Solan, India Email: krishansharmakd@rediffmail.com

Received: July II, 2018 | Published: July 26, 2018

Copyright@ 2018 Sharma et al. This is an open access article distributed under the terms of the Creative Commons Attribution License, which permits unrestricted use, distribution, and reproduction in any medium, provided the original author and source are credited.

\begin{abstract}
Bell pepper is one of the most important horticultural commodities of commercial importance owing to the presence of flavonoids, carotenoids and vitamin C. This is one of the main export produce of Israel. Export and local market both demand high quality vegetables, possessing long shelf-life and freshness at the market. The main aim of this study was to evaluate the effect of modified atmosphere packaging using two different packaging materials viz., Xtend $\mathbb{B}(\mathrm{XF})$ and polyethylene (PE) films at $1.5^{\circ} \mathrm{C}, 7^{\circ} \mathrm{C}$ and $17^{\circ} \mathrm{C}$ storage temperatures. Fruits were evaluated for total soluble solids, gaseous composition, colour, firmness, elasticity, weight loss, chilling injury, decay and sensory parameters to assess the quality and shelf-life. XF and PE minimized weight loss and maintained firmness and freshness. Further, $\mathrm{XF}$ reduce the development of decay in the fruits stored at $7^{\circ} \mathrm{C}$ and chilling injury at $1.5^{\circ} \mathrm{C}$. The fruit storage was best at $7{ }^{\circ} \mathrm{C}$ using XF packaging.
\end{abstract}

Keywords: capsicum, xtend film, temperature, MAP, storage

\section{Introduction}

Bell pepper (Capsicum annuum L.) is an American commodity which originated in Mexico, Central America and Northern South America ${ }^{1}$ and its commercial cultivation started in Spain in the middle of the $17^{\text {th }}$ century. ${ }^{2}$ Bell pepper is a cultivar group of Capsicum annuum species, member of the night shade Solanaceae family, which also includes potato, tomato and eggplant. It is popular horticultural commodities in different regions of the world and is the second most important horticultural crop in Israel with 189,149 tonnes produced in $2016 .^{3}$ Israel has conducted research in protected cultivation and postharvest of this commodity and notable success has been achieved in maintaining quality and extending storage life by adopting different postharvest practices thus allowing export of this commodity to markets in Europe and North America.

Export and local market both demand high quality sorted fruits, which possess long shelf-life and freshness. ${ }^{1}$ Pepper importing countries may also require quarantine security protocols against the Mediterranean fruit fly (Medfly) and fruits must be certified as free of Medfly. ${ }^{4}$ The uniformity and appearance of fruits also have a significant effect on product choice by the consumer. Bell pepper quality is determined by attributes like colour, shape, size, taste, texture, firmness, weight, and internal chemical composition. Quality also depends on the preferences and requirements of consumers. ${ }^{5}$ The principal physiological factors of pepper quality that are negatively impacted during shipment, storage and marketing are water loss and chilling injury. ${ }^{6-10}$ Studies suggest that packing pepper inside plastic bags creates a modified atmosphere within storage, reducing its susceptibility to water loss and chilling injury. ${ }^{11}$ However, other authors reported that modified atmospheric storage did not affect weight loss or softening. ${ }^{12}$

Sweet pepper can be stored for moderately long periods at temperatures between $7^{\circ} \mathrm{C}$ and $13^{\circ} \mathrm{C}$, depending upon the variety and the stage of maturity. ${ }^{13}$ Main factors of quality degradation of sweet pepper during storage include decay development, susceptibility to chilling injury and shriveling associated to rapid water loss, which limits storage at temperatures above $7^{\circ} \mathrm{C} .{ }^{13}$ Water loss in commercial bell pepper has been identified as the main physiological factor limiting pepper fruit quality and prolonged storage. ${ }^{8}$ Furthermore, reduced temperatures do not completely inhibit decay development during prolonged storage and red pepper has been found as the most perishable..$^{13,14}$

Modified atmosphere packaging (MAP) is a technology used to extend the shelf-life of fruits and vegetables of high commercial value. Packaging of pepper in perforated plastic films and storing them at optimum temperature could be one of the viable alternatives to extend shelf-life. Manolopoulou et $\mathrm{a}^{15}$ have demonstrated that by 
using polyvinyl chloride (PVC), low density polyethylene (LDPE) and medium density polyethylene (MDPE) packaging of different $\mathrm{O}_{2}$ / $\mathrm{CO}_{2}$ permeability, it is possible to generate a model associating mass loss, firmness of bell peppers and the packaging films. Packaging bell peppers with polyethylene bags at low temperature $\left(7.5^{\circ} \mathrm{C}\right)$ reduced the water loss by $40-50 \%$ and maintained the fruit quality. ${ }^{13}$ The use of packaging films has been shown to increase the shelf-life of perishable produce establishing a beneficial in-package atmosphere containing low $\mathrm{O}_{2}$ and high $\mathrm{CO}_{2}$ and reduced water loss. ${ }^{16} \mathrm{Xtend}^{\circledR}$ films (StePac LA Ltd, Israel) have been developed to modify atmosphere and humidity for prolonged packaging. Rodov et $a l^{17}$ have suggested that this packaging material prolonged shelf-life of fresh produce such as melon, broccoli and green onions, among other products. Therefore, the main aim of this study was to evaluate the effect of modified atmosphere packaging of bell pepper at different storage temperatures in order to determine the ideal packaging material to maintain their physical and chemical properties without compromising the quality.

\section{Materials and methods}

\section{Sample preparation}

Bell pepper (Capsicum annuum L. cv Kannon) were harvested at optimum maturity determined by the firmness and the onset of colour change from the Arava Desert of Israel in January 2014. The fruit were washed, graded and stored at optimum storage temperature until further study. Eight, randomly selected fruits were used for each treatment (Table 1) and experiment was replicated 3 times and standard deviation of the mean value in each parameter was calculated. Fruits were assessed for total soluble solids, colour, firmness, elasticity and weight before storage under different packaging conditions. Following initial measurements, fruit samples were stored at $1.5^{\circ} \mathrm{C}$, $7^{\circ} \mathrm{C}$ and $17^{\circ} \mathrm{C}$ under different atmosphere conditions depending on the plastic material used viz., Control with no bag, Xtend ${ }^{\circledR}$ film (XF) and Polyethylene (PE) film. Three Samples each containing eight fruits were evaluated at the beginning of the experiment (Day 0) and after two weeks of storage (Day 14) for different physico-chemical and sensory parameters. Samples kept at $1.5^{\circ} \mathrm{C}$ and $7^{\circ} \mathrm{C}$ for 11 days were subjected to a further three-day storage period at $17^{\circ} \mathrm{C}$. Samples kept at $17^{\circ} \mathrm{C}$ were stored for 14 days without temperature change.

Table I Experimental design of Bell pepper stored under different conditions*

\begin{tabular}{llll}
\hline \multirow{2}{*}{ Packing material } & \multicolumn{3}{l}{ Storage temperature } \\
\cline { 2 - 4 } & $\mathbf{I . 5 ^ { \circ } \mathbf { C }}$ & $\mathbf{7}^{\circ} \mathbf{C}$ & $\mathbf{1 7} 7^{\circ} \mathbf{C}$ \\
\hline Control & $\mathrm{T}_{1}$ & $\mathrm{~T}_{2}$ & $\mathrm{~T}_{3}$ \\
Xtend $^{\circledR}$ film (XF) & $\mathrm{T}_{4}$ & $\mathrm{~T}_{5}$ & $\mathrm{~T}_{6}$ \\
Polyethylene film (PE) & $\mathrm{T}_{7}$ & $\mathrm{~T}_{8}$ & $\mathrm{~T}_{9}$ \\
\hline
\end{tabular}

*Relative Humidity (RH): 94\%

\section{Texture analysis}

Fruit firmness and elasticity was measured using a pressure tester, as described by Ben-Yehoshua et al. ${ }^{18}$ Each fruit was placed horizontally between two flat plates, a $2 \mathrm{~kg}$ weight was placed on top of the upper plate, and the deformation of the fruit in millimeters was expressed. The full deformation was measured after $3 \mathrm{sec}$ of initial force application onto fruits and recorded as firmness. Pressure was then removed, and the residual deformation was measured and regarded as the capacity of a body to recover its original shape (Elasticity).

\section{Total soluble solids}

Bell peppers were diced and juice was taken out by squeezing the material. Total soluble solids were measured by placing a drop of pepper juice (approximately $0.1 \mathrm{~mL}$ ) on the lens of the refractometer (Palette, PR-32 $\alpha$, Atago, Japan). Results were expressed in percentage of soluble solids.

\section{Colour analysis}

Colour analysis was conducted by capturing the reflectance using a Chroma meter (Minolta, CR-300, Osaka, Japan) at two different areas of each bell pepper marked for the said purpose. The Hue angle was recorded and represented the tangent of $\mathrm{a}$ and $\mathrm{b}$ values from the Lab colour scale (i).

$H^{o}=\tan (b / a)$

\section{Weight loss}

Bell peppers were weighed at the beginning of the experiment and at the end of the experiment. The weight loss (WL) percentage was calculated according to equation (ii) where the final weight (FW) was related to the initial weight (IW) of each sample.

$$
W L(\%)=\frac{(I W-F W)}{I W} \times 100
$$

\section{Gaseous composition}

Concentrations of oxygen $\left(\mathrm{O}_{2}\right)$ and carbon dioxide $\left(\mathrm{CO}_{2}\right)$ were recorded by using a portable gas analyzer (Oxybaby ${ }^{\mathbb{B}} 6.0$, WittGasetechnik, Witten, Germany) and expressed as a percentage during the experiment. Two samples were taken from each treatment and data were expressed in percentage of each gas.

\section{Chilling injury and decay}

Visual evaluation of fruits was conducted at the end of the experiment (Day 14) to assess decay and chilling injury. The incidence of mould infestation was recorded and results were expressed as percentage of decayed fruit compared to the entire population. Chilling injury appeared as pitting on the fruit surface. Symptoms were evaluated visually after storage. An index was used to express results for mild (1), moderate (2) and severe (3) chilling injury. A null value (0) was assigned to samples which did not contain injury.

\section{Sensory evaluation}

At the end of storage (Day 14), samples were drawn from each treatment to assess sweetness, texture, juiciness, and off-flavor by a panel of judges. Three samples were analyzed as per the treatment and data were expressed in a 5-point scale for each attribute evaluated.

Eight, randomly selected fruits were used for each experiment and three experiments were carried out each time. The mean of three replicated experiment for each quality parameter was calculated and data were expressed as Mean \pm Standard Deviation.

\section{Results and discussion}

The data generated during the assessment period were analyzed and the information is presented in the Tables (2 and 3 ) and Figures (1-6) below: 
Table 2 Elasticity, gaseous composition and total soluble solids of Bell pepper stored for I4 days at various temperatures and packaging materials

\begin{tabular}{|c|c|c|c|c|c|c|}
\hline \multirow{2}{*}{ Packing Material } & \multirow{2}{*}{$\begin{array}{l}\text { Temp' } \\
\left({ }^{\circ} \mathrm{C}\right)\end{array}$} & \multicolumn{2}{|l|}{ Elasticity } & \multicolumn{2}{|c|}{ Gaseous atmosphere (\%) } & \multirow{2}{*}{$\begin{array}{c}\text { Total Soluble Solids } \\
\text { (\%) }\end{array}$} \\
\hline & & $(\mathrm{mm})$ & (\%) & $\mathbf{O}_{2}$ & $\mathrm{CO}_{2}$ & \\
\hline \multirow[t]{3}{*}{ Control $^{2}$} & $\begin{array}{l}1.50 \\
7.00\end{array}$ & $\begin{array}{l}3.25 \pm 1.3 \\
3.38 \pm 0.7\end{array}$ & $\begin{array}{l}41.9 \pm 6.9 \\
38.2 \pm 7.0\end{array}$ & $\begin{array}{l}21.0 \pm 0.0 \\
21.0 \pm 0.0\end{array}$ & $\begin{array}{l}0.30 \pm 0.0 \\
0.30 \pm 0.0\end{array}$ & $\begin{array}{l}5.70 \pm 1.8 \\
7.73 \pm 1.0\end{array}$ \\
\hline & 17.0 & $4.38 \pm 1.0$ & $32.7 \pm 6.4$ & $21.0 \pm 0.0$ & $0.30 \pm 0.0$ & $7.60 \pm 0.3$ \\
\hline & 1.50 & $2.69 \pm 0.9$ & $46.1 \pm 11$ & $18.4 \pm 0.1$ & $3.85 \pm 0.2$ & $7.53 \pm 0.3$ \\
\hline \multirow[t]{3}{*}{ Xtend $^{\circledR}$ film } & 7.00 & $3.00 \pm 0.9$ & $45.6 \pm 7.6$ & $19.1 \pm 0.1$ & $2.70 \pm 0.6$ & $7.37 \pm 0.2$ \\
\hline & 17.0 & $3.69 \pm 1.0$ & $35.4 \pm 5.5$ & $19.0 \pm 0.1$ & $2.70 \pm 0.1$ & $8.53 \pm 2.0$ \\
\hline & 1.50 & $2.56 \pm 0.7$ & $48.6 \pm 6.6$ & $19.2 \pm 0.0$ & $2.15 \pm 0.2$ & $6.67 \pm 0.4$ \\
\hline \multirow[t]{2}{*}{ Polyethylene film } & 7.00 & $2.25 \pm 0.6$ & $43.0 \pm 4.2$ & $19.1 \pm 0.0$ & $2.20 \pm 0.0$ & $7.17 \pm 0.4$ \\
\hline & 17.0 & $2.94 \pm 1.1$ & $47.4 \pm 4.9$ & $19.3 \pm 0.1$ & $1.90 \pm 0.1$ & $6.70 \pm 0.0$ \\
\hline Initial conditions ${ }^{3}$ & & $3.13 \pm 0.5$ & $51.9 \pm 4.2$ & $21.0 \pm 0.0$ & $0.30 \pm 0.0$ & $7.09 \pm 0.6$ \\
\hline
\end{tabular}

'Temperature of storage; ${ }^{2}$ Samples stored without bagging; ${ }^{3}$ Measurements were conducted on the entire lot before subjecting samples to different storage conditions

Table 3 Colour measurements, chilling injury and decay of Bell pepper stored under various temperatures and atmospheres for 2 weeks

\begin{tabular}{|c|c|c|c|c|c|}
\hline \multirow[t]{2}{*}{ Packing Material } & \multirow{2}{*}{ Temp' ( $\left.{ }^{\circ} \mathrm{C}\right)$} & \multicolumn{2}{|c|}{ Hue Angle $\left(\mathbf{H}^{\circ}\right)$} & \multirow{2}{*}{ Chilling Injury ${ }^{3}$} & \multirow{2}{*}{ Decay $^{3}$ (\% } \\
\hline & & Day 0 & Day 14 & & \\
\hline \multirow{3}{*}{ Control $^{2}$} & 1.50 & $19.1 \pm 3.5$ & $15.4 \pm 3.5$ & $1.25 \pm 0.7$ & $0 \%$ \\
\hline & 7.00 & $22.0 \pm 2.6$ & $13.8 \pm 2.0$ & $N / A^{4}$ & $25 \%$ \\
\hline & 17.0 & $18.8 \pm 2.9$ & $13.5 \pm 1.5$ & $\mathrm{~N} / \mathrm{A}$ & $38 \%$ \\
\hline \multirow{3}{*}{ Xtend $®$ film } & 1.50 & $16.7 \pm 2.3$ & $14.3 \pm 2.1$ & $1.00 \pm 0.0$ & $0 \%$ \\
\hline & 7.00 & $18.0 \pm 3.0$ & $12.4 \pm 2.4$ & $\mathrm{~N} / \mathrm{A}$ & $0 \%$ \\
\hline & 17.0 & $20.0 \pm 3.5$ & $|5| \pm 3.1$. & $N / A$ & $38 \%$ \\
\hline \multirow{3}{*}{ Polyethylene film } & 1.50 & $18.8 \pm 5.6$ & $15.5 \pm 4.5$ & $1.13 \pm 0.6$ & $38 \%$ \\
\hline & 7.00 & $19.4 \pm 4.5$ & $14.3 \pm 2.9$ & $N / A$ & $63 \%$ \\
\hline & 17.0 & $\mid 8.1 \pm 2.9$ & $13.6 \pm 2.4$ & N/A & $38 \%$ \\
\hline
\end{tabular}

ITemperature of storage; ${ }^{2}$ Samples stored without bagging; ${ }^{3}$ Results are reported at the end of the experiment (Day I4); ${ }^{4}$ Not applicable

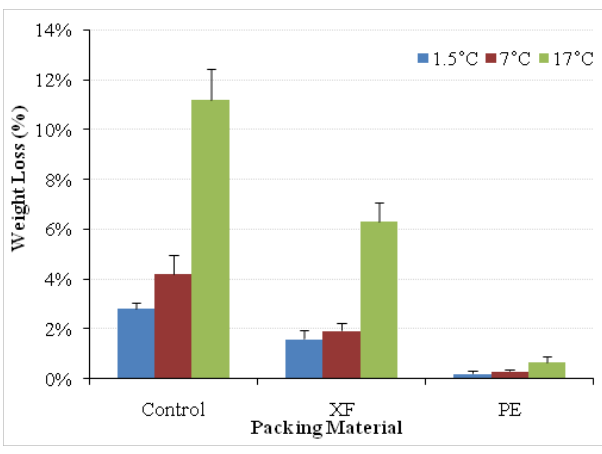

Figure I Effect of packing material and storage temperature on weight loss [Control: No packing material; XF: Xtend ${ }^{\circledR}$ film; PE: Polyethylene film].

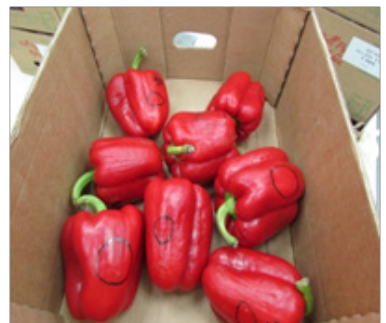

$\mathrm{A}\left(17^{\circ} \mathrm{C}\right)$

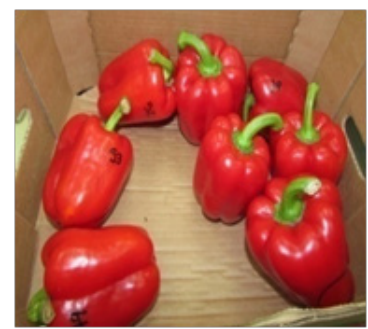

$\mathrm{B}\left(7^{\circ} \mathrm{C}\right)$

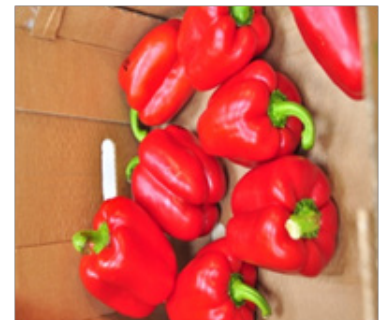

$\mathrm{C}\left(1.5^{\circ} \mathrm{C}\right)$
Figure 2 Shriveled Bell pepper of control treatment after 14 days of storage at different temperatures. 

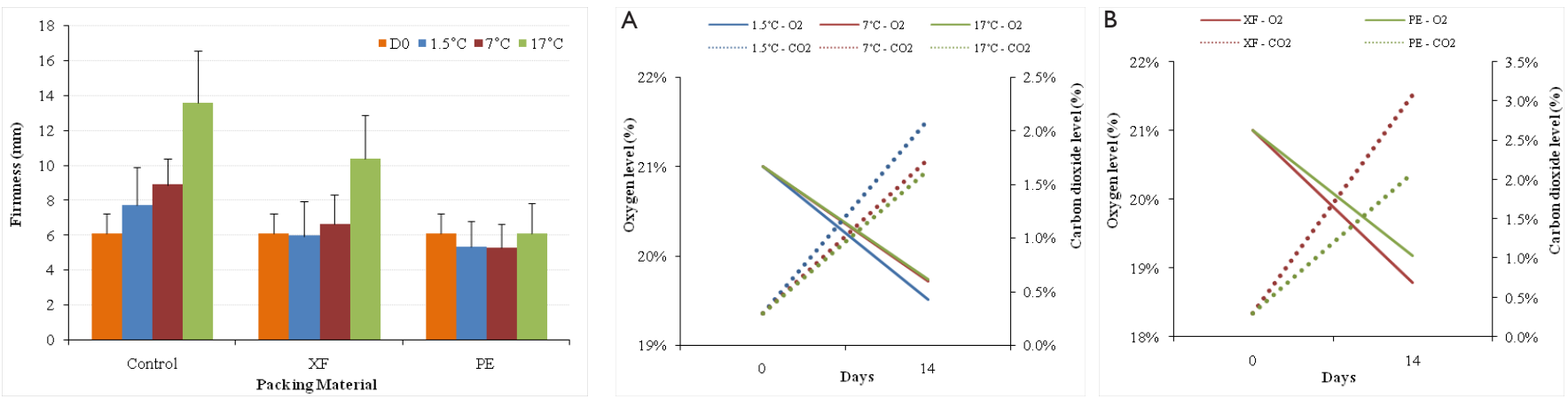

Figure 3 Effect of packing material and storage temperatures on firmness [D0: Measurements at day 0; Control: No packaging material; XF: Xtend ${ }^{\circledR}$ film; PE: Polyethylene film].
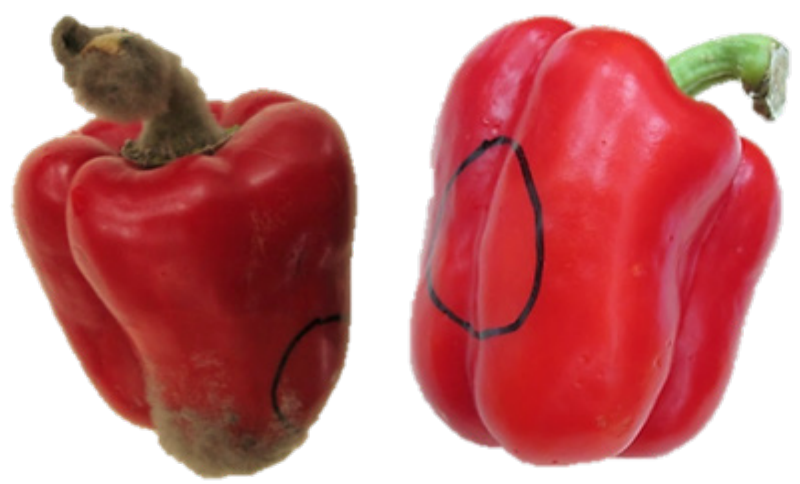

Figure 5 Incidence of decay and chilling injury in Bell pepper after 2 weeks.

\section{Weight loss}

The physiological loss in weight is represented in Figure 1. Control samples of Bell peppers stored at $17^{\circ} \mathrm{C}$ had the maximum loss in weight $(11 \%)$ followed by the samples of peppers packed in Xtend ${ }^{\circledR}$ film stored at the same temperature $(6 \%)$. There was minor loss in weight for the samples packed in polyethylene irrespective of the storage condition. In general, all the control samples (No packing film) stored at all the 3 temperatures had considerable weight loss during the storage and shelf-life period of 14 days. More percentage of weight loss was recorded in highly shriveled Bell pepper of the control treatment after 14 days of storage at $17^{\circ} \mathrm{C}$ (Figure 2).

Fruits and vegetables are living commodities which continue to respire and transpire even after their detachment from the parent plants. When these commodities are attached to the parent plant, the loss in water and the substrate is replenished but once they are detached, they have to maintain themselves on their reserves. Respiration is one of the important physiological processes important to maintain the living nature of the commodity after harvest and during storage. Therefore, the main goal during storage is to restrict the respiration and transpiration processes to delay the ripening and senescence thereby maintaining the quality, shelf-life and marketability of the produce. Modified atmosphere packaging is a postharvest technology that regulates storage conditions to maintain the quality of fresh produce..$^{15}$

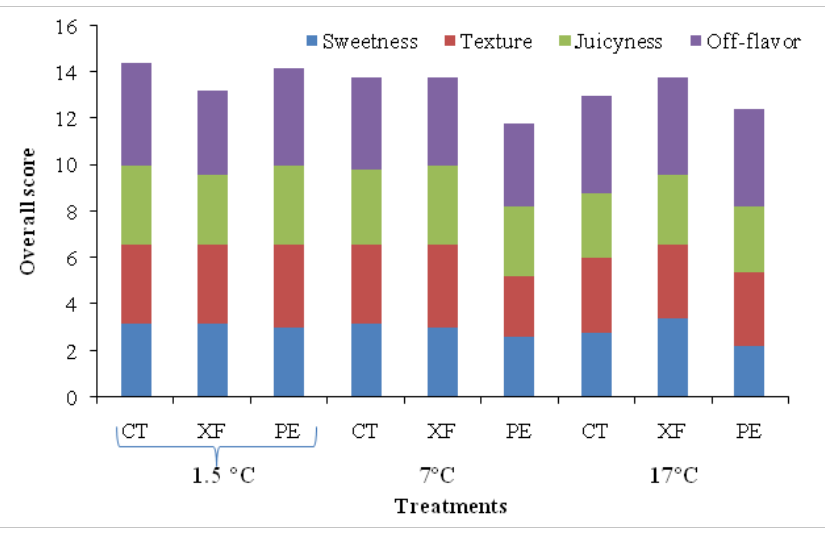

Figure 6 Sensory analysis of bell peppers after 14 days of storage [CT: Control with no packing material; XF: Xtend $₫$ film; PE: Polyethylene film].

The packing films and storage temperatures used in this experiment i.e. Xtend ${ }^{\mathbb{R}}$ film and polyethylene film have clearly shown that it is possible to curtail the loss in weight at a storage temperatures of $1.5^{\circ} \mathrm{C}$ and $7^{\circ} \mathrm{C}$. However, peppers packed in $\mathrm{Xtend}^{\circledR}$ film stored at $17^{\circ} \mathrm{C}$ showed significant loss which could be attributed to increase in respiration and transpiration rate at this temperature. The permeability of films to moisture and gases is directly responsible to the loss in weight. Polyethylene films acted as a complete barrier to moisture whereas $X \mathrm{Xtend}^{\circledR}$ film showed permeability to moisture at all storage temperatures with maximum levels at $17^{\circ} \mathrm{C}$.

\section{Firmness and elasticity}

Fruit firmness and elasticity was assessed on samples after a 14-day storage period. At the beginning of the study, samples were already soft according to the scale used ${ }^{13}$, which suggested that fruits over $3 \mathrm{~mm}$ of firmness were considered soft (Figure 3). This could be attributed to the shelf-life of peppers used for this experiment as they were stored for a significant period of time prior to this experiment. Storage temperature and packing material had a significant effect on the firmness of samples. Firmness in fruit was decreased as storage temperature increased. Samples with no packing material (control) showed the lowest firmness which coincided with water loss of samples. Firmness was maintained in samples stored in $\mathrm{Xtend}^{\circledR}$ films except when storage temperature was $17^{\circ} \mathrm{C}$ where firmness 
was reduced by 71 percent. Polyethylene film showed best results in maintaining firmness despite of storage temperature.

Elasticity is the difference between the initial firmness and the capability of the fruit to recover its initial form. Results suggested that initial samples had a higher elasticity $(52 \%)$ while samples stored for 14 days at various temperatures and packing materials reduced its capacity to recover its original shape (Table 2). Results showed that samples stored with packing materials (XF and PE) maintained more elasticity with losses of $6 \%$ of the original values. Only samples stored with $\mathrm{XF}$ at $17^{\circ} \mathrm{C}$ showed a reduction of more than $15 \%$ which was similar to values in samples with no packing material (Control). Temperature also showed an impact on loss of elasticity especially in control samples. As storage temperature increased, elasticity was diminished losing almost $20 \%$ of the original elasticity (Control samples at $17^{\circ} \mathrm{C}$ ).

Firmness and elasticity properties of fruits and vegetables are related to the structures present in cell walls such as pectin, cellulose and hemi-cellulose. These carbohydrates are susceptible to enzyme attack and other biological processes during ripening. ${ }^{19-21}$ Enzymes responsible for fruit softening include cellulase, pectin methyl esterase, polygalacturonase, $\beta$-galactosidase, among others. ${ }^{19,22}$ The breakdown of theses polymers leads to the formation of smaller particles hence, the reduction of firmness and integrity of the samples, and water loss among other changes in fruits and vegetables are not desirable during storage. ${ }^{19,23,24}$

\section{Total soluble solids}

Table 2 shows that fruit stored at $7^{\circ} \mathrm{C}$ displayed an increase in total soluble solids (TSS). The fruit packed in Polyethylene (PE) film showed a decrease when stored at $1.5^{\circ} \mathrm{C}$ and $17^{\circ} \mathrm{C}$. This increase in TSS during MAP storage of bell pepper is consistent with the findings of Aguilaret $\mathrm{al}^{25}$ and Sakaldas and Kaynas. ${ }^{26}$ An increase in TSS content particularly the sugars may indicate ripening and the use of packaging is to delay this process. ${ }^{25}$ An increase in TSS may also be a result of breakdown of other complex sugars such pectin, which is broken down by either (or both) the fruit's own enzymes, as well as by microbial enzymes. Overall, the treatments which exhibited a decrease in TSS were considered to be less optimal because this might indicate a reduction in sugars, which are an important quality parameter i.e. sweetness for Bell pepper as will be discussed later. However, the change in TSS during storage period did not exhibit any specific trends and it is important to consider this parameter in combination with the other quality parameters to determine quality loss.

\section{Gaseous atmosphere}

The results of gaseous composition for different packing materials and storage temperatures are presented in Table 2. $\mathrm{O}_{2}$ and $\mathrm{CO}_{2}$ concentration for different treatments varied in between 18.4 $21.0 \%$ and $0.3-3.85 \%$, respectively. Maximum $\mathrm{CO}_{2}(3.85 \pm 0.2 \%)$ concentration was observed in the samples packed in Xtend ${ }^{\circledR}$ films and stored at $1.5^{\circ} \mathrm{C}$ for 14 days while the minimum $(1.90 \pm 0.1 \%)$ in the polyethylene packing stored at $17^{\circ} \mathrm{C}$ (Figure 4).

Normal atmospheric composition of three major gases is $78.0 \% \mathrm{~N}_{2}$, $20.8 \% \mathrm{O}_{2}$ and $0.3 \% \mathrm{CO}_{2}$. During modified atmospheric storage, the gaseous composition varies according to the type of packing material and storage temperature. Depending upon the packaging barrier for different gases, the concentration of $\mathrm{O}_{2}$ decreases and $\mathrm{CO}_{2}$ goes up.
Although, there was no control in the gaseous atmospheres in the packages used (XF and PE), the alteration of the normal gaseous composition due to respiration helped in extending the quality and shelf-life of the produce. Limited respiration is always desirable during the storage of vegetables which give rise in the concentration of $\mathrm{CO}_{2}$ production inside the package thus preventing mould growth such as Alternaria alternata and Botrytis cinerea. ${ }^{16}$

Besides, optimum storage temperature and humidity inside the package are also responsible for better preservation and decay control. More the respiration rate more will be the production of $\mathrm{CO}_{2}$ i.e. fast utilization of the substrate, making unfit the commodities for human consumption. In this study, packing material, depending upon the temperature of storage, contributed in the reasonable production of $\mathrm{CO}_{2}$. No off-flavour was noticed in our samples irrespective of the packaging and storage condition thereby suggesting that the packages had sufficient $\mathrm{O}_{2}$ to prevent fermentation as a source of energy. In-spite of reasonable $\mathrm{CO}_{2}$ build up inside the polyethylene film, mould growth was noticed, which could be attributed to vapours build-up inside the bags. In the absence of sufficient $\mathrm{O}_{2}$ in the packing atmosphere during storage, anaerobic respiration leads to the production of acetaldehydes and alcohol leading to off-flavour. ${ }^{27}$ The ratio of $\mathrm{CO}_{2}$ and $\mathrm{O}_{2}$ in various treatments was within the prescribed limits thus causing no harm to peppers in terms of flavour. Production of comparatively more $\mathrm{CO}_{2}$ in Xtend ${ }^{\circledR}$ films stored at $1.5^{\circ} \mathrm{C}$ could be attributed to the initial volume of $\mathrm{O}_{2}$ and $\mathrm{CO}_{2}$ in the packs while sealing the bags at day 0 and/ or due to subsequent higher respiration rate when the samples of this treatment were put at $17^{\circ} \mathrm{C}$ to simulate retail market conditions. Differences in gaseous composition build up in Xtend ${ }^{\circledR}$ films and polyethylene films at different temperatures in storage could be attributed to the selective barrier properties of these films to gases and moisture. ${ }^{28} \mathrm{Xtend}^{\circledR}$ films with reasonable production of $\mathrm{CO}_{2}$ definitely proved better in controlling the quality without having any mould growth, decay and off-flavour.

\section{Colour}

The results in Table 3 show that the change in colour at $1.5^{\circ} \mathrm{C}$ and $17^{\circ} \mathrm{C}$ was similar across all treatments. At $7^{\circ} \mathrm{C}$, the change in colour was larger in the control, which might be an indication, that packaging at this temperature plays a role in delaying further ripening. Other researchers have shown the ability of packaging films such as PE to delay ripening. ${ }^{29,30}$ Our results show that there is no significant difference between the two packaging materials in delaying colour development.

\section{Chilling injury and decay}

Chilling injury of the fruit was reported for storage at $1.5^{\circ} \mathrm{C}$, at temperatures above $7^{\circ} \mathrm{C}$, no chilling injury was observed as expected, in line with the findings of previous work. ${ }^{26,31}$ After the storage period, chilling injury was noted as mild for the control and all treatments. This indicates that the packaging material used had no significant effect in the prevention of chilling injury. Previous researchers have used hot water treatments ${ }^{26,32}$ prior to storage in MAP environment, to reduce chilling injury.

Table 3 shows that XF packaging was more effective in the prevention of decay. In the control, decay was exhibited at $7^{\circ} \mathrm{C}$ and $17^{\circ} \mathrm{C}$, while the fruit stored in PE packaging showed some decay at all storage temperatures. Decay was visible as fungal mycelia on the fruit calyx and surface, as well as rotting (spots) on the fruit surface (Figure 5). 
The susceptibility of fruit in PE packaging to decay is probably due to the low permeability of the packaging material resulting in high relative humidity which is conducive for fungal growth. ${ }^{26}$ This high relative humidity was visible as water droplets were found on the fruit in PE packaging. These results show that overall XF packaging appears to be suitable for decay prevention during storage.

\section{Sensory evaluation}

Figure 6 shows that the results of the sensory evaluation were similar across treatments. There was no apparent significant difference between packing materials in the overall score based on sensory analysis. It should be noted that none of the decayed fruit were sampled with regards to sensory parameter. This might be a limitation in the accurate determination of the outcomes of this experiment. However, $\mathrm{XF}$ scored highest over $\mathrm{PE}$ and control at various temperatures suggesting that this is the best packaging material for the storage of bell pepper.

\section{Conclusion}

Use of packing materials viz., Xtend ${ }^{\circledR}$ film and Polyethylene film to modify the atmospheric conditions have shown to maintain the quality of Bell pepper during storage at an optimum temperature of $7^{\circ} \mathrm{C}$. Furthermore, Xtend ${ }^{\circledR}$ packaging proved to be ideal for the storage based on prevention of decay, minimizing weight loss, maintaining firmness, elasticity and scored well in the sensory evaluation. No differences were observed in total soluble solids, colour, chilling injury and sensory characteristics.

\section{References}

1. Ignat T. Non-destructive methods for determination of quality attributes of bell peppers. 2012.

2. Guerra M, Magdaleno R, Casquero PA. Effect of site and storage conditions on quality of industrial fresh pepper. Sci Hortic. 2011;130(1):141-145.

3. FAOSTAT. http://www.fao.org/faostat/.

4. Fallik E, Perzelan Y, Alkalai-Tuvia S, et al. Development of cold quarantine protocols to arrest the development of the Mediterranean fruit fly (Ceratitis capitata) in pepper (Capsicum annuum L.) fruit after harvest. Postharvest Biol Technol. 2012;70:7-12.

5. Abbott JA. Quality measurement of fruits and vegetables. Postharvest Biol Technol. 1999;15(3):207-225.

6. Watada AE, Kim SD, Kim KS, et al. Quality of green beans, bell peppers and spinach stored in polyethylene bags. J Food Sci. 1987;52(6):16371641.

7. Lownds NK, Banaras M, Bosland PW. Relationships between postharvest water loss and physical properties of pepper fruit (Capsicum annuum L.). HortScience. 1993;28(12):1182-1184.

8. Maalekuu K, Elkind Y, Tuvia-Alkalai S, et al. Quality evaluation of three sweet pepper cultivars after prolonged storage. Adv Hortic Sci. 2003:187191.

9. Smith DL, Stommel JR, Fung RW, et al. Influence of cultivar and harvest method on postharvest storage quality of pepper (Capsicum annuum L.) fruit. Postharvest Biol Technol. 2006;42(3):243-247.

10. Rao TR, Gol NB, Shah KK. Effect of postharvest treatments and storage temperatures on the quality and shelf life of sweet pepper (Capsicum annum L.). Sci Hortic. 2011;132:18-26.
11. Forney CF, Lipton WJ. Influence of controlled atmospheres and packaging on chilling sensitivity. Chill Inj Hortic Crops. 1990:257-267.

12. Polderdijk JJ, Boerrigter HAM, Wilkinson EC, et al. The effects of controlled atmosphere storage at varying levels of relative humidity on weight loss, softening and decay of red bell peppers. Sci Hortic. 1993;55(34):315-321.

13. Meir S, Rosenberger I, Aharon Z, et al. Improvement of the postharvest keeping quality and colour development of bell pepper (cv.'Maor') by packaging with polyethylene bags at a reduced temperature. Postharvest Biol Technol. 1995;5(4):303-309.

14. Mohammed M, Wilson LA, Gomes PI. Effects of postharvest dips on the storage quality of fruit from two hot pepper (Capsicum frutenscens) cultivars. Trop AgricTrinidad. 1991;68:81-87.

15. Manolopoulou H, Xanthopoulos G, Douros N, et al. Modified atmosphere packaging storage of green bell peppers: quality criteria. Biosyst Eng. 2010;106(4):535-543.

16. Kader AA, Zagory D, Kerbel EL, et al. Modified atmosphere packaging of fruits and vegetables. Crit Rev Food Sci Nutr. 1989;28(1):1-30.

17. Rodov V, Horev B, Vinokur Y, et al. Modified-atmosphere packaging improves keeping quality of charentais-type melons. HortScience. 2002;37(6):950-953.

18. Ben-Yehoshua S, Shapiro B, Chen ZE, et al. Mode of action of plastic film in extending life of lemon and bell pepper fruits by alleviation of water stress. Plant Physiol. 1983;73(1):87-93.

19. Lazan H, Selamat MK, Ali ZM. $\beta$-Galactosidase, polygalacturonase and pectinesterase in differential softening and cell wall modification during papaya fruit ripening. Physiol Plant. 95(1):106-112.

20. Brummell DA, Harpster MH. Cell wall metabolism in fruit softening and quality and its manipulation in transgenic plants. Plant Mol Biol. 2001;47(1-2):311-339.

21. Abu-Goukh A-BA, Bashir HA. Changes in pectic enzymes and cellulase activity during guava fruit ripening. Food Chem. 2003;83(2):213-218.

22. Posé S, Paniagua C, Cifuentes $\mathrm{M}$, et al. Insights into the effects of polygalacturonase FaPG1 gene silencing on pectin matrix disassembly, enhanced tissue integrity, and firmness in ripe strawberry fruits. $J$ Exp Bot. 2013;64(12):3803-3815.

23. Giovannoni JJ, DellaPenna D, Bennett AB, et al. Expression of a chimeric polygalacturonase gene in transgenic rin (ripening inhibitor) tomato fruit results in polyuronide degradation but not fruit softening. Plant Cell. 1989;1(1):53-63.

24. Atkinson RG, Sutherland PW, Johnston SL, et al. Down-regulation of POLYGALACTURONASE1 alters firmness, tensile strength and water loss in apple (Malus x domestica) fruit. BMC Plant Biol. 2012;12(1):129.

25. González Aguilar GA, Cruz R, Baez R, et al. Storage Quality of Bell Peppers Pretreated with Hot Water and Polyethylene Packaging. $J$ Food Qual. 22(3):287-299.

26. Sakaldas M, Kaynas K. Biochemical and quality parameters changes of green sweet bell peppers as affected by different postharvest treatments. Afr J Biotechnol. 2010;9(48):8174-8181.

27. Brückner B, Wyllie SG. Fruit and Vegetable Flavour: Recent Advances and Future Prospects. Elsevier; 2008.

28. Massey LK. Permeability Properties of Plastics and Elastomers: A Guide to Packaging and Barrier Materials. William Andrew; 2003.

29. Yuen CMC. Effect of postharvest calcium and polymeric films on ripening and peel injury in Kensington Pride mango. Asean Food J Malays. 1993. 
30. Pesis E, Aharoni D, Aharon Z, et al. Modified atmosphere and modified humidity packaging alleviates chilling injury symptoms in mango fruit. Postharvest Biol Technol. 2000;19(1):93-101.

31. Paull RE. Chilling Injury of Horticultural Crops: Chilling Injury of Crops of Tropical and Subtropical Origin. CRC Press; 1990.
32. Porat R, Pavoncello D, Peretz J, et al. Induction of resistance to Penicillium digitatum and chilling injury in 'Star Ruby' grapefruit by a short hot-water rinse and brushing treatment. J Hortic Sci Biotechnol. 2000;75(4):428-432. 